\title{
River management under transformation: The emergence of strategic adaptive management of river systems in the Kruger National Park
}

\author{
Authors: \\ Sharon Pollard ${ }^{1}$ \\ Derick du Toit ${ }^{1}$ \\ Harry Biggs ${ }^{2}$ \\ Affiliations: \\ ${ }^{1}$ Association for Water \\ and Rural Development, \\ Acornhoek, South Africa \\ ${ }^{2}$ South African National \\ Parks, Skukuza, South Africa \\ Correspondence to: \\ Sharon Pollard \\ Email: \\ sharon@award.org.za \\ Postal address: \\ Private Bag X420, Acornhoek \\ 1360 , South Africa \\ Dates: \\ Received: 22 June 2010 \\ Accepted: 22 Feb. 2011 \\ Published: 13 May 2011 \\ How to cite this article: \\ Pollard, S., Du Toit, D. \& \\ Biggs, H., 2011, 'River \\ management under \\ transformation: The \\ emergence of strategic \\ adaptive management of \\ river systems in the Kruger \\ National Park', Koedoe \\ 53(2), Art. \#1011, 14 pages. \\ doi:10.4102/koedoe \\ v53i2.1011
}

C 2011. The Authors. Licensee: OpenJournals Publishing. This work is licensed under the Creative Commons Attribution License.
Protected areas such as the Kruger National Park (KNP) face many management challenges, of which ensuring a healthy flow of rivers into the park is one of the most important. Although previous management policies isolated the KNP from its neighbours, this position has changed as the KNP seeks to negotiate a respected 'place' for water and conservation in a competitive environment. A major catalyst for this re-orientation has been the response from the KNP to the growing water crisis where its position needed to be seen within the wider catchment and policy context in South Africa. This paper presents an overview of the transforming management practices of the KNP in a changing political, socio-economic and environmental context, through the lens of water resources. We show that the KNP management model moved beyond inward-looking, isolationist policies to adopt responsivity to major change factors. The new approach was applied first in the sphere of river management in the KNP after which it spread to other domains such as fire and game management. It explicitly incorporates an experimental-reflexive orientation and considers management as a process of learningby-doing. This paper strives to review the transformation since the onset of explicit adaptive management of these rivers. The development of a new stewardship, based on a stakeholdercentred vision and on learning-focused management, has been a main achievement for the KNP. A closer partnership between researchers, managers and field staff, supported with buyin and co-learning, has led to a management framework based on a clear vision informed by stakeholder involvement, an objectives hierarchy, a scoping of management options, a monitoring system and a reflective evaluation process with feedback loops. Although developed through a focus on rivers, the framework can be embraced for the management of ecosystems as a whole.

Conservation implications: The explicit adoption of strategic adaptive management for the rivers entering the KNP has had considerable implications not only with regard to management practice within the park, but also for the relationships with neighbours. This has also meant setting and implementing new goals and priorities with managers and staff.

\section{Introduction} The broader context of the development of a management response approach
in the Kruger National Park

Protected areas such as the Kruger National Park (KNP) face many daunting management challenges, of which ensuring a regular and healthy flow of rivers through the park is arguably one of the most important. Although previous management policies isolated the KNP from its neighbours, the park is not an 'island' (Pollard, Shackleton et al. 2003). The park's responses to the growing water crisis (Pollard \& Du Toit 2011) are increasingly being referenced against the wider context of water management in South Africa, which includes attention to the new water legislation and options for negotiating a respected 'place' for water and conservation in a competitive economic environment.

The aim of this paper is to present an overview of the adaptive management practices of the KNP in a changing political, socio-economic and environmental context, from a water resource perspective. It tracks the park's approach to water management as it changed from inwardlooking, isolationist policies to one focused on responsivity to major change factors (Venter et al. 2008).

Water is an interesting lens through which to examine managerial transformation in the park because, as a fugitive resource, it 'knows no boundaries'. For research and management to be meaningful, one should therefore look beyond the boundaries imposed by administrative and 
political systems. In this regard the KNP is - within South Africa, at least - the 'downstream user' of six major rivers that traverse or border the park. A wider view recognises that South Africa and the KNP lie upstream of or adjacent to international neighbours Mozambique, Zimbabwe and Swaziland, with whom water must be shared and managed (Figure 1). Thus, no account would be complete without consideration to the wider context within which the KNP is embedded. An in-depth account of the socio-economic and environmental profile of the this context has appeared in several publications (e.g. Dovie, Shackleton et al. 2006; Niehaus 2001; Pollard et al. 2003; Pollard, Biggs et al. 2008; Ramutsindela 2002; Stadler 1994) and hence we provide only an overview here to highlight major characteristics.

The KNP is located in the Lowveld, an area that includes the $\mathrm{KNP}$ and an additional stretch of land around it (50 km wide) on the park's western border (see Pollard et al. 2003). The rivers that traverse the KNP cross into Mozambique, where the Lowveld extends to coastal floodplains and estuaries. The landscape includes a rich variety of landforms, climate and vegetation, as well as cultures and land uses. The climate is tropical to subtropical, with drought being endemic to the region (Tyson 1986). The Drakensberg escarpment, exceeding $1800 \mathrm{~m}$ a.s.l., descends rapidly eastward to the Lowveld of the KNP and Mozambique, with average altitudes of $600 \mathrm{~m}$ and $400 \mathrm{~m}$, respectively. Similarly, yearly rainfall declines from more than $1200 \mathrm{~mm}$ along the escarpment to less than $450 \mathrm{~mm}$ at the eastern border with Mozambique.

At least two million people live within $50 \mathrm{~km}$ of the western border of the KNP, with some 500000 on the eastern border in the area of Mozambique included in the Great Limpopo Transfrontier Conservation Area (GLTFCA) (Cumming and AHEAD 2004, although according to personal communication with D. Cumming, demographic data are uncertain). There is a diversity of cultures and major groups include the Tsonga, the Vhavenda, the Pedi and the Swazi. In South Africa these

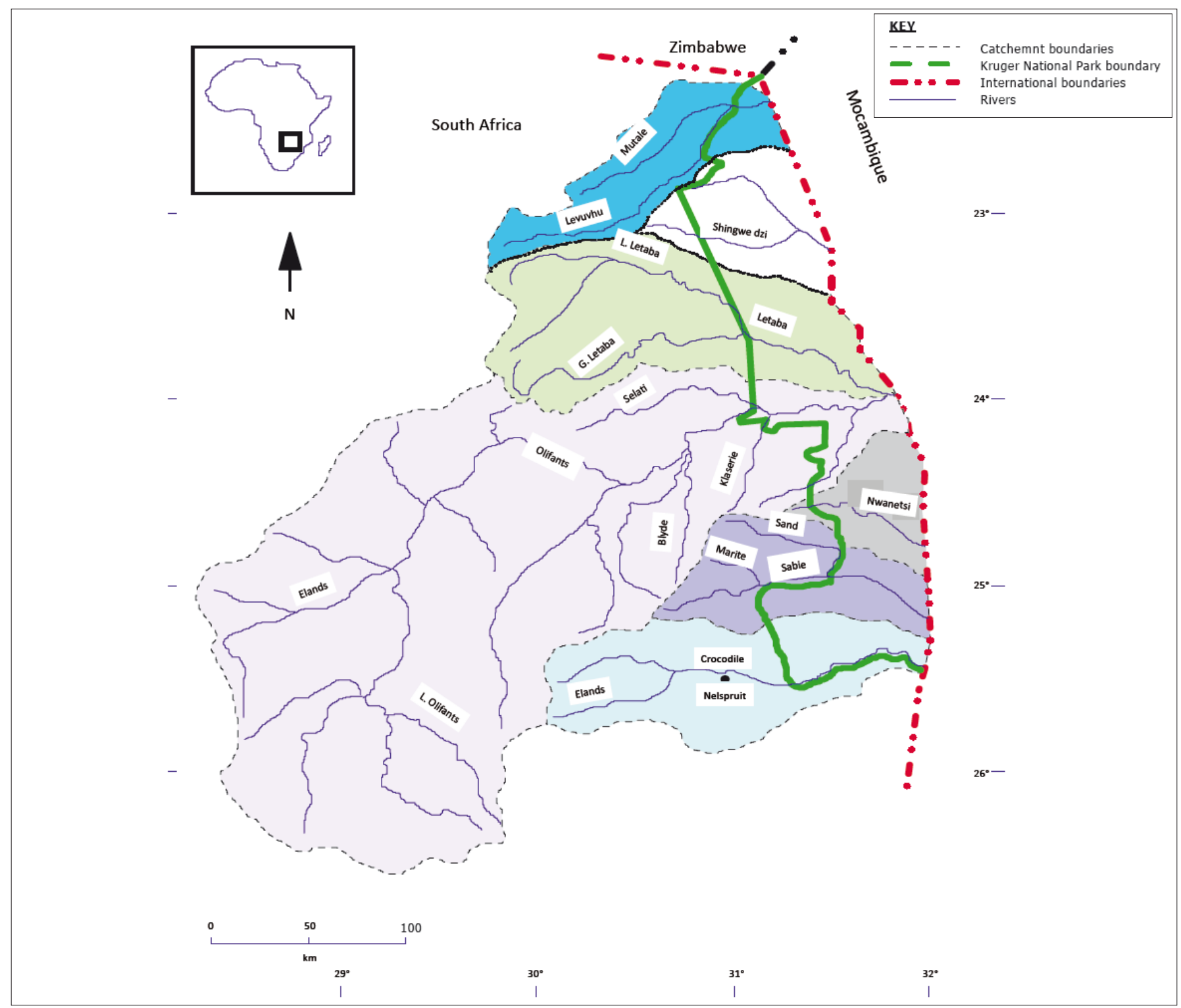

FIGURE 1: Map indicating the major river systems and associated catchments of the eastern escarpment, lowveld and Kruger National Park, South Africa. Anthropogenic changes have meant that of the six historically perennial systems, only the Sabie River has remained so. 
groups were segregated under the apartheid government into the former bantustans of Gazankulu, Venda, Lebowa and KaNgwane, respectively, from the late 1960s until the first democratic government was elected in 1994.

In contrast to the adjacent, sparsely settled commercial farms historically owned largely by whites (5-20 people per square kilometre), these former homelands experienced densities as high as 300 people per square kilometre as a result of forced relocations (Pollard, Mendiguren et al. 1998). The legacy of apartheid means that the former bantustan areas are still characterised by high levels of poverty today, with large disparities (especially between people living inside and outside these areas) in access to water, sanitation, education and employment opportunities as well as attendant environmental degradation as people tried to eke out a living on marginal land (Pollard et al. 1998). Since 2002, with new conservation ventures being launched, a part of Mozambique was incorporated into what is the easterly component of the Great Limpopo Transfrontier Park (GLTP) and the GLTFCA. As was the case with the 'homelands' in South Africa people living here also experienced a series of re-settlements - in this case due to colonial rule, the civil war and now the GLTP (Refugee Research 2002).

The period between the 1960s and the 1980s was marked by economic expansion, mainly in the form of commercial agriculture, including afforestation, and some limited mining (see Pollard, Riddell. et al. 2010). During this time water was considered only insofar as it was needed. In keeping with global practices, water deficits were dealt with through increased infrastructure such as dams and interbasin transfers (Pearce 1992). Issues of sustainability or equity were of little concern and, indeed, this period of uncontrolled development was unconstrained by water resources.

By the early 1990s, South Africa faced some major sociopolitical changes, which were to have a direct impact on the KNP (see Carruthers 1995; Pollard et al. 2003; Pollard $\&$ Du Toit 2007). The high density of poor people on the western boundary lead to an environmental and economic situation that fostered conflict over land and resources (Stadler 1994). The collapse of the apartheid regime and the establishment of a democratic government in 1994 heralded the transformation of the politico-legal environment in South Africa. Owing to changes to land ownership policies and land reform, the future of the park and the definition of its boundaries are now embedded in a different socio-political climate. Protected area legislation underwent transformation, which redirected conservation endeavours to reflect the intentions of the South African Constitution. The former legislation that goverened parks was replaced by the new Protected Areas Act in 2003. Legislation with regard to water resources underwent a fundamental re-orientation with the promulgation of the National Water Act in 1998 (South Africa 1998), moving from a system of riparian rights to one in which there is no private ownership of water but rather state custodianship. Underlying the transformation is the challenge of redressing past inequities and supporting development whilst ensuring the sustainability of the resource base upon which livelihoods and a healthy environment is founded. Sustainability, together with equity, took centre stage with the recognition of the Reserve as a constitutional right to water (Department of Water Affairs and Forestry 2004). The National Water Act of 1998 defines the Reserve as a quantity of water to sustain basic human needs and to ensure the sustainability of the resource itself. A major change was that water was to be managed from a more holistic, catchment perspective with consideration to stakeholder participation. This signalled a recognition of linkages - not only between upstream and downstream use or between land and water, but also between people and resources - in water resource production and management.

It is in this context that the democratic government of South Africa has re-orientated the management of water resources, and the KNP responded by adopting new policies and management approaches. This paper aims to provide a synthesis of a number of research initiatives that have been launched since formal adaptive management was first explicitly adopted in the early 1990s, most notably Phases II and III of the KNP Rivers Research Programme (KNPRRP), Ecosystems, Protected Areas and People Project of the International Union for Conservation of Nature (IUCN-EPP) and more recent work under the Shared Rivers Initiative (SRI) (Pollard \& Du Toit 2011). Perhaps because of the key importance of freshwater, and the variability inherent in river function, adaptive management arose first in the river context in the KNP and later spread to other areas of natural resource management in the park (Freitag et al., in review). The KNPRRP ended in 2000 and has been fairly well documented as an entity (Breen et al. 2000), but relatively little new development or documentation emerged since.

Although the KNP continued to implement adaptive protocols Catchment Management Agencies (CMAs) were anticipated to be formed to allow the work of the KNPRRP to be put into practice. However, real-world lags led to delays, which eventually triggered a feeling that the KNPRRP should have continued. A new action research initiative was thought to be needed for further work, which led to the eventual formulation of the SRI in 2007 (see Pollard and Du Toit [2011] for a full description). However, between 2000 and 2005, a separate research programme, known as the River Savanna Boundaries Programme, was run in the KNP with collaborators from South Africa and the United States. The programme focused on landscape ecology and on the links between riverine and terrestrial systems, which contributed greatly to the understanding of heterogeneity as an organising factor in ecosystems. The programme helped to mainstream the heterogeneity paradigm in the KNP and also, generally, in the minds of savanna scientists, particularly because of a very successful annual meeting started under the auspices of the programme and the subsequent publication of The Kruger Experience: Ecology and management of savanna heterogeneity (Du Toit et al. 2003) assisted by funding from the programme. 
An opportunity arose in 2004 under the IUCN-EPP to document the experience and lessons learned from the KNPRRP. The purpose of the IUCN-EPP was to enable managers of protected areas to implement, in the face of global change, adaptive management strategies through a number of mechanisms, one of which was to document lessons from key case studies such as that of the KNP. The authors subsequently conducted research along with a range of park staff regarding the changing nature of river research and management (Pollard \& Du Toit 2006, 2007). By 2007, the need for consequences and lead-ons from the KNPRRP led to the start of the SRI. The SRI has since examined the complexities of achieving compliance with the environmental water requirements (EWR) of the Lowveld rivers that flow through the park (Pollard \& Du Toit 2009). In South Africa EWRs, also known as the Ecological Reserve, are used as benchmarks for assessing sustainability in freshwater resources (see, for example, Pollard and Du Toit [2008]). Sustainability is one of the cornerstones of the 1998 National Water Act.

Within the KNP two key change factors frame contemporary management practices, which are fundamentally different from those of the past. The first is the alarming decline in surface water quality and quantity (Pienaar 1970), together with the associated biodiversity changes of the rivers that flow through the KNP (see later). The second is the recognition that Lowveld savannas are not stable-state agricultural systems but rather that heterogeneity and flux are inherent characteristics (Du Toit, Rogers et al. 2003; Peel 1999; Rogers \& O'Keeffe 2003). In retrospect, it is interesting to note how closely interlinked the histories of these factors have been and some suggest that their mutual influence has guided transformed management of the KNP over the past 15 years (Pollard \& Du Toit 2005; Van Wilgen \& Biggs 2010).

These factors had a number of implications. Firstly, because all six perennial rivers originate outside of the park, the KNP has had to broaden its areas of engagement to include a catchment-based perspective. This situation is not unique to the KNP; many of the world's protected areas rely on rivers of which the catchment areas are not co-incident with park boundaries. Secondly, in recognition of the dynamic nature of ecosystems (and indeed the socio-ecological system, as described by Pollard, Biggs et al. [2008]), the KNP embarked on an approach that explicitly incorporates an experimental orientation and which views management as adaptive, that is, learning by doing (Kingsford et al. 2011). The co-evolution and influence of these two factors will be explored in the following sections. Another notable aspect to this overview is how the practical outcomes of an adaptive approach - development of an objectives hierarchy and thresholds of potential concern (TPCs) - have been extended far beyond the management of water alone (Freitag et al. in review) and now frame all aspects of ecosystem management (such as fire and herbivores) in the KNP. What transpired was the complete overhaul of a management approach: a change from one of immutable goals and objectives based on stable-state ecosystem theory to one based on learning- management iterations designed to maintain variability, which is a fundamental attribute of semi-arid savannas and rivers (Davies, O'Keeffe et al. 1995). We wish to use the narrative of water resources management to elaborate on the adaptive management approach and its evolution within the KNP.

\section{The worsening situation: a brief overview of the Lowveld water resources}

Changes to the river systems have been evident since the 1960s (Pienaar 1970) and since then most systems have experienced progressive degradation in quantity and quality and associated fauna and flora. Of the six river systems of the Park, five were perennial and one, the Shingwedzi, was naturally seasonal (O'Keeffe \& Davies 1991). The first deterioration was evident already some 45 years ago when the perennial Letaba ceased flowing and subsequent cessations have transformed this river into a non-perennial system. A similar situation occurred in the Luvuvhu River in the 1960s and later in the Olifants River. The Crocodile River has experienced flow constancy as well as a seasonal reversal as a result of regulation (see Pollard \& Du Toit 2010), and both the Crocodile and Olifants have suffered heavy pollution and invasion by alien plant species. The Sabie River is regarded as the least perturbed of the major rivers of the KNP, with relatively small distributional changes in fish species (Russell \& Rogers 1988). In comparison, an (at least transient) loss of species has characterised the other KNP rivers: the Letaba, Olifants and Crocodile rivers appeared to have lost between four and six fish species, and the Luvuvhu River has lost nine species. Most of these have re-appeared at lower abundances.

Agricultural abstraction is regarded as the primary driver for the increasing demands on the water resources (O'Keeffe \& Davies 1991; Pollard, Riddell et al. 2010). That, together with afforestation and in some areas mining, has been implicated in the hydrological modifications evident today (Chunnett 1990; Water Research Commission 2001). This situation has been exacerbated by the past allocation inequities between the various user sectors and has been accompanied by escalating tensions. For example, the Sand River catchment boasts the highest percentage of afforestation of any catchment in South Africa, and the associated reduction in streamflow (Smith \& Scott 1992) has led to disputes between timber growers and other downstream users during past dry cycles (Pollard et al. 1998). Recent studies have indicated that all Lowveld catchments, with the exception of the Sabie, are in water deficit (demand exceeds availability) or will be once the requirements for the Ecological Reserve are met (DWAF 2004a,b,c; DWAF 2009; Pollard, Riddell. et al. 2010).

The aridity of the Lowveld and the frequency of drought, coupled with current and projected population densities and water demands, mean that there is insufficient water to meet current needs at the required assurance levels in most catchments (Pollard et al. 1998). This situation provided a drive for further water resource developments, mainly in the 
form of dams, although the enthusiasm for impoundments has waned somewhat since 1994, and has been replaced by a more integrated approach to water resource management (Pollard et al. 2007), in which the KNP has been instrumental in setting the tone. Indeed, in some cases this has meant reviewing and revising earlier policies and actions to the extent that dams within the park, such as the Shimuwini Dam (Figure 2), have been destroyed

\section{Water for Game Programme: Attempts to dampen variability}

Already in the 1970s the Warden of the KNP realised that upstream impacts on the river systems were being felt within the park and correctly surmised that these were likely to worsen. At that time his concerns focused primarily on the potential loss of herbivore species because of insufficient water for game. Initially he prevailed upon government to act, but soon adopted an inward-looking approach, reasoning that the interests of irrigators and forestry were too pervasive and powerful to counteract.

The resultant Water for Game programme was designed to support herbivore populations during drought through a network of reliable water points (such as drinking troughs supplied by boreholes) and the construction of weirs and sluices, which were to mitigate upstream impacts by ensuring the adequate flow of perennial rivers during droughts (Pienaar 1970). In total, some 400 boreholes, dams, sluices and weirs were built, but as Gaylard et al. (2003) note, the intended benefits did not materialise. As prudent as this policy may have seemed at the time, it was detrimental in two respects. Firstly, the numbers of game, especially of rare antelope like roan, did not improve in the longer run - probably because of the competition with escalating zebra populations - and herbivore numbers continued to fluctuate (see e.g. Owen-Smith \& Ogutu 2003). Secondly, the use of surface water influenced faunal, and hence vegetation, distribution patterns at multiple scales, because the water point distribution ensured that the majority of the land was within $5 \mathrm{~km}$ of a permanent water source (Gaylard et al. 2003).

Although, with the benefit of hindsight, it is easy to see the shortcomings of this policy, it certainly was in keeping with the dominant management approaches of the time. All strongly interventionist in nature, the strategies were designed to reduce variability and unpredictability (Mabunda et al. 2003). It is only in the past decade or so that new thinking, with heterogeneity at the forefront, has really come into its own. A detailed account is beyond the scope of this paper but it is instructive to note the breadth of this thinking detailed in The Kruger experience: Ecology and management of savanna heterogeneity (Du Toit, Rogers et al. 2003).

\section{Small sections of rivers and catchments in the Kruger National Park}

If the length of rivers or area of catchments that fall within the park are examined (Figure 3), the linkages and vulnerability of the park to external influences are starkly apparent, with almost all the associated catchment areas falling largely outside of the KNP boundaries. The most contained system is the Sabie, which is relatively short, with $110 \mathrm{~km}$ of its total length of $190 \mathrm{~km}$ falling within the park. On the other hand, in the Olifants, a severely degraded system, only a 100-km-long stretch of its total length of $840 \mathrm{~km}$ (or 11\%) falls within the $\mathrm{KNP}$, accounting for a mere $8 \%$ of the catchment area. Only $25 \%$ of each of the catchments of the Crocodile and Letaba rivers fall within the park, and some $36 \%$ and $18 \%$ of the river lengths, respectively. Although $61 \%$ of the catchment area of the Luvuvhu falls within the park, this accounts for only $34 \%$ of the river length. Moreover, all the major river systems flowing eastwards through the KNP ultimately feed Mozambique (Figure 1) and under international obligations South Africa is required to honour certain flows through to that country. The KNP thus sits between two realities: on the one hand, it is the victim of upstream use and abuse and, on the other, it acts as a buffer for Mozambique downstream,
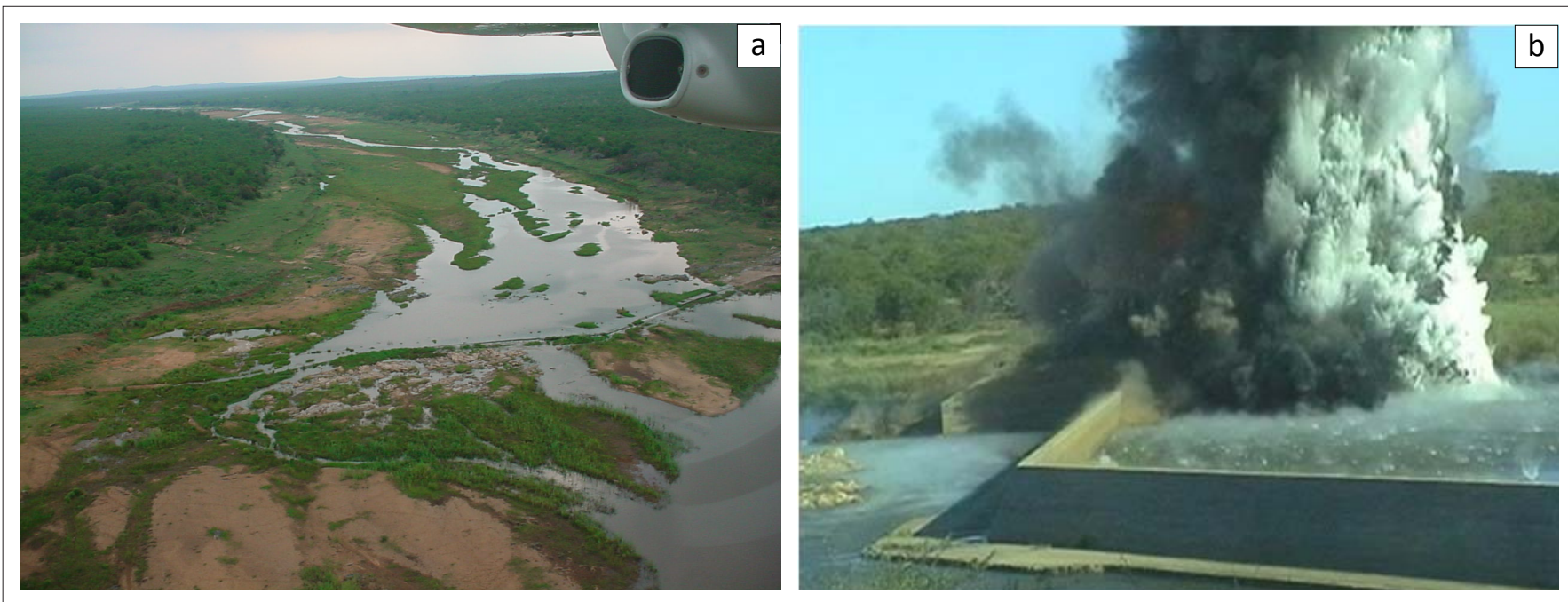

Source: Photo taken by F. Venter

FIGURE 2: (a)The Shimuwini Dam and (b) its removal in 2004. 
through partly securing the water demands which will flow on into that country.

\section{Institutional arrangements}

Against this precarious situation, we explore the response of the KNP, which, as for the examples of fire and borehole provision, has transformed over time. What is distinctive about rivers is that owing to their fugitive nature, KNP management was forced to look beyond the park borders for potential solutions (Venter et al. 2008) and to devise monitoring and management responses that were embedded in a wider socio-political landscape. The KNP has influenced institutional arrangements (Biggs et al. 2008) and has undertaken, or at times initiated, engagement in wider water management actions such as catchment strategy development, international agreement revision, water quality monitoring and even legal action. Mitigatory actions taken with respect to, for instance, maintaining the flow of the Sabie during the 1992 drought (Venter \& Deacon 1995) and in the Letaba River (Pollard \& Du Toit 2008) would otherwise not have succeeded. Indeed, the role of the KNP as 'watchdog' (the first agency to alert water managers and society in general of a river problem) has been highlighted by Pollard and Du Toit (2008) as essential to functional feedback loops.

In the political climate that has prevailed since 1994, stakeholder involvement, transparency and accountability are regarded as key tools for achieving equity and sustainability. This means that the KNP can no longer operate as a conservation island, because such policies compel it both to be involved and to partake in wider stakeholder discussions within its expanded, albeit 'informal', borders for water resources negotiations. The National Water Act (1998) outlines institutional arrangements for the management of water through the Catchment Management Agencies operative for 19 Water Management Areas (WMAs). The KNP straddles three WMAs:

- the Inkomati (incorporating the Sabie and Crocodile rivers within the Inkomati River basin, an international drainage basin shared by South Africa, Swaziland and Mozambique)
- the Olifants

- the Luvuvhu-Letaba.

Both the Olifants and Luvuvhu-Letaba systems form part of the Limpopo Basin in Mozambique. Although only the Inkomati WMA has been gazetted thus far, it has set a precedent in that a seat for conservation is reserved in the composition of the board. This places the onus for participation on the conservation sector (and especially the $\mathrm{KNP}$ ) and affords a much stronger voice than in the past.

\section{The formal adaptive response: Developing a strategy to respond to the challenges posed by declining river system integrity The KNP Rivers Research Programme and
adaptive management}

Until the late 1980s, river management per se was not explicit as a park objective other than park authorities asking the (then) Department of Water Affairs and Forestry (DWAF) for special releases from upstream dams. Nonetheless, by the late 1980s the development of water quality guidelines seemed to signal a resurgence of belief that the KNP could exert constructive pressure on external agencies above ad hoc requests for releases, for instance, from the Tzaneen Dam. Additionally, DWAF announced its intentions to allocate water for environmental flows in rivers as it became obvious that if demands were unchecked, the integrity of rivers would be threatened (DWAF 2004). Despite these intentions, estimates were limited to preliminary calculations and based on absolute amounts of water. Indeed, the first formal recognition of water for instream flow needs for South African rivers was by Roberts (1983), who used an allocation for 'conservation' of $11 \%$ of the country's mean annual runoff (later modified to $8 \%$ of the exploitable water resources by Jezewski and Roberts [1986]). Roberts acknowledged that this figure was simplistic in that it was based on coarse, countrywide estimates of water for estuaries, lakes and nature reserves. As such, it could not be used for individual rivers (see also Breen et al. [1994]), but nonetheless provided the catalyst for future work. Researchers contested this figure and pointed to the paucity of understanding regarding

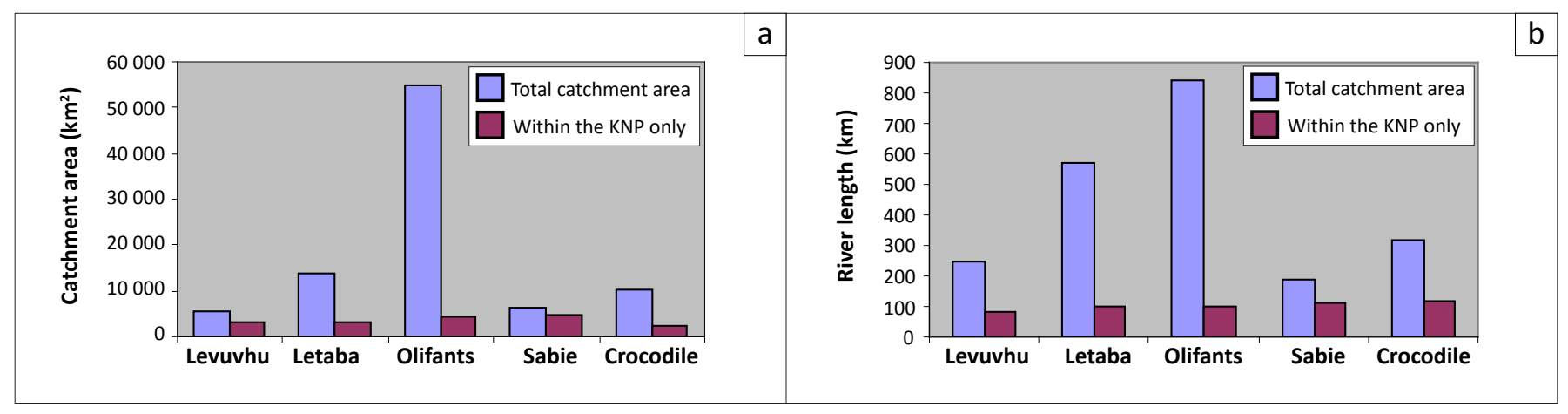

KNP, Kruger National Park; km², 1 square kilometer.

FIGURE 3: A comparison of (a) total catchment areas and (b) river lengths of the five perennial river systems found within the KNP (from Pollard, S.R. \& Du Toit, D., 2007, 'Guidelines for Strategic Adaptive Management: Experiences from managing the rivers of the Kruger National Park, South Africa', IUCN/ UNEP/GEF Project No. GF/ 271303-4679, Ecosystems, Protected Areas and People Project, Planning and managing protected areas for global change). 
Lowveld river systems as a major challenge to management for sustainability of the rivers. Ultimately a much more sophisticated and ground-breaking approach for calculating riverine water requirements was developed by a South African team (King et al. 2000) and prototyped through the KNPRRP and other research initiatives in South Africa (see later).

By 1988 the KNPRRP was conceptualised and initiated as a co-operative undertaking by managers or resource users, funding agencies and researchers (Breen, Dent et al. 2000). The KNPRRP consisted of three phases (Appendix 1). Phase I (1989-1993), which ran for four years, was largely limited to scientific research. The focus was on a range of research topics relating to environmental water requirements but was unstructured in detail (O'Keeffe \& Coetzee 1996). Moreover, managers within the KNP were not convinced that, in practical terms, the research outputs supported the continuing management crises that they experienced (H. Biggs, pers. comm.). In 1991, the newly constructed Zoeknog Dam in the upper Sand catchment collapsed, delivering sediment for weeks into the river, a phenomenon that persisted through the KNP and into Mozambique (Weeks, Pollard et al. 1992). Such a patent demonstration of undesirable consequences of poor design or construction compelled the Park to respond through radio interviews and public platforms. It had not been customary before this for the Park or their associated researchers to respond, signalling the start of a more public voice for the KNP. It again highlighted the need for directed research that could support managers in their response to short-term crises. Other research in the programme examined the potential fragility of the system, such as the effects on fish of being confined to shrinking pools (Pollard, Weeks et al. 1994) and vegetation changes associated with reed-bed colonisation (Carter \& Rogers 1989).

A comprehensive review of Phase I recommended a second phase (1994-1996), with greater emphasis on predictive capabilities and management action, which was to be more intimately linked to a decision making system. It was during this phase that collaboration between managers and researchers improved with some co-learning. Researchers began responding more explicitly to short-term crises experienced by managers, and managers benefited from the longer-term view provided by researchers. The political transformations that accompanied democratic transitions in 1994 were also major drivers for change, creating opportunity for far more effective international engagement. In 1995 the KNPRRP hosted an international conference on Integrated Catchment Management in Skukuza, a concept which was receiving increasing attention within the DWAF itself. This served to focus interests on holistic water resources management and, interestingly, raised the profile of international issues associated with water sharing across country borders.

At about the same time, research interest in complexity theory and adaptive management within natural resource management started to grow. These ideas arose as a critique of approaches based on averages and the propensity to view nature as balanced, linear and predictable. Variability, in fact, was highlighted as the key characteristic of semi-arid systems (Davies, O'Keeffe et al. 1995). Even where ranges were recognised (e.g. introducing a variation of between 7000 and 9000 in KNP elephant numbers), it was still not appreciated that savanna ecosystems need more extremes than these slight fluctuations to build resilience. This paradigm suggests that the recognition of variation and extreme events are fundamental for biodiversity management. This idea was central to the determination of environmental flows where variation in flow regimen was seen as a key driver of the system. The building-block approach (King et al. 2000) introduced the concept of incorporating freshes (small and intermediate floods) into a flow regimen, which were seen as essential linkages to certain key biotic or abiotic events such as spawning or sediment flushing.

Other concerns at the time centered on the entrenched and 'command-and-control' nature of management within the KNP (Biggs \& Rogers 2003; Du Toit, Rogers et al. 2003). The imperative of political transformation necessitated change from one of an insular approach of managing the park, separate from its neighbours, to one which attempts to embed the KNP within the socio-economic landscape and encourages wider participation, transparency and public ownership. Moreover, the entrenched science-management activities such as monitoring were aligned with a facilitated, 'learning-by-doing' approach. The conservation of protected savannas in Africa has been dominated by a focus on charismatic species and, as mentioned, influenced by stablestate concepts such as carrying capacity, with less emphatic regard for scale or the inherent dynamics of ecosystems. The previous approach has been challenged for its failure to embrace spatial heterogeneity and flux in ecosystems and for not always recognising a fuller array of compositional, structural and functional elements of biodiversity and ecosystems (Noss 1990). Indeed, a recent publication centred on the theme of heterogeneity in the KNP (Du Toit et al. 2003) bears testimony to this fundamental shift in thinking. This raised a number of questions and challenges for the research and management community. Firstly, what research was needed to elucidate the important characteristics of heterogeneity? Secondly, how was management to embrace such variability and flux as the norm and when would the 'variability norm' be unacceptably exceeded? As noted by Rogers (2005), strategic adaptive management (SAM), and its associated objectives hierarchy, is one of the few recognised models for managing uncertainty in interactive social and ecological systems, whilst still aiming purposefully at a carefully articulated (but assumed to be shifting) desired state.

As explained, river management was in crisis during the early 1990s and despite a vigorous initiative on the part of the KNPRRP and a few SANParks associates, most managers in the KNP had not internalised that river management was an explicit part of their brief.

Interestingly, another important co-driver of the change in KNP management was the 'impasse' on elephant culling, 
which came to a head at about the same time as the KNPRRP underwent a major reorientation (Freitag et al. in review). Heated public debate and scrutiny called for reforms to the culling programme and a moratorium on culling was introduced (Van Aarde, Whyte et al. 1999). This essentially set the scene for other programmes to be influenced by the thinking that had developed in the KNPRRP. Notably, a conference to discuss elephant management was held in Skukuza and this provided an opportunity for participants to examine progress that had been made within the KNP management framework. The key conclusions were that (1) the vision and objectives cascading from this vision needed to be improved and (2) elephants need to be managed as part of an ecosystem (Braack 1997a).

This led to the revision of the entire KNP management plan (Braack 1997a, b), starting with a visioning exercise of which the learnings and elements were already available through the KNPRRP. Under the theme of accountability, the KNP had to go public with its objectives. At the time, the KNPRRP was in the process of exploring and prototyping the concept of defining and operationalising the desired future state (DFS) of rivers (Rogers \& Bestbier 1997). Through collaborative efforts between the KNP management and the KNPRRP, the application of this concept was explored for use beyond river management alone. Much of the philosophy behind the DFS is that, as a public participation process which arrives at a joint agreement, much of the potential conflict can be reduced. After clear objectives were set as an objectives hierarchy, questions arose as to what needed to be monitored to achieve these objectives. A large collaborative meeting between managers and researchers in the KNP heralded the start of measurable endpoints, known as TPCs (see, for example, Braack et al. [1997], McLoughlin WRC 2011. and Pollard and Du Toit [2007]). As described elsewhere, these TPCs are intimately embedded in an adaptive management framework. Critically, they are set against the background of complex systems, representing spatio-temporal flux, often with lower and upper limits (see McLoughlin et al. [2011] for a comprehensive review of river-related TPCs).

The third phase of the KNPRRP (1998-2000) was designed to enable the completion of first-generation procedures and technologies to support SAM of rivers and to promote corrective action through the participation of stakeholders, especially those who had previously been marginalised. The need for a more holistic approach also prompted creative thinking around the issue of integrated catchment management and the role of SAM in this regard. It could be argued that, given the leadership and close relationship between key individuals in the KNPRRP, DWAF and the Water Research Commission (WRC), who funds water research in South Africa, a strong learning alliance was formed, albeit informal. Many of the ideas emerging from the KNPRRP and the process of water law reform were echoed in WRC research reports and were mutually reinforcing. For example, today notions of SAM are embedded within certain strategic documents and guidelines of DWAF. Moreover, the approach is now firmly embedded in Scientific Services within SANParks on an ongoing basis. Although not named as such, a new phase of work was initiated in 2007 (after being discussed for several years) to build on that of the KNPRRP. It was driven by scientists' and managers' questions as to the apparent lack of improvement in the status of the rivers despite the advent of the National Water Act. The intention was to deepen the understanding surrounding the casues for the lack of improvement. About a year later the KNP also recognised the need to strengthen its own adaptive management of the rivers and also initiated an associated project, both of which will now be discussed.

\section{A new phase of research: Linking outputs to management}

The KNPRRP was followed by a hiatus in programmatic river research until the conceptualisation of the two initiatives, both quite distinct from the earlier rivers programme, and both strongly focused on action research and adaptive management processes. One of these, introduced earlier as the SRI (Pollard \& Du Toit 2008), focused on understanding the factors that enable or constrain meeting the commitment to the Ecological Reserve in six river systems flowing through the KNP (Luvuvhu, Letaba, Olifants, Sabie-Sand, Crocodile and Komati). The intention was to build supportive programmes in Phase II due to commence in 2010. The other closely linked project aimed to consolidate the SAM process for freshwater management in the park, mainly by operationalising the TPCs through effective sciencemanagement links (Biggs et al. 2003; 2008; 2010). Primarily as a result of findings from the SRI, which identified case situations that were amenable to effective study, the current focus is on the Letaba and Crocodile rivers. In both cases there is strong evidence of feedback loops between key role players. Feedback loops and self-organisation are considered to be essential components of resilient systems and adaptive management (Biggs \& Rogers 2003a; Holling 2001; Holling \& Gunderson 2002). Feedback is the basis for learning in a reflexive system. Where systems often fail is where one or more of these steps fail such as in cases where the learning is not passed on or is passed to an inappropriate body. When functional, these loops set up a self-organising system that is responsive to change.

As recognition for this approach grows, so does the interest in what makes the feedbacks work (see Pollard et al. 2008). In the Letaba catchment, for example, a number of key feedback loops of self-organisation and self-regulation are evident (Figure 4). The KNP monitors flows against the Reserve requirements (which have until recently been static; that is, not actively dynamic in line with current exact rainfall) and, on detecting problems, the Water Affairs manager (who manages the Tzaneen Dam), in turn, alerts the Groot Letaba Water Users Association to curtail use. They, in turn, inform users of curtailment rules and monitor adherence. Although not always popular, the regulatory system is respected and adhered to by the members. 
There are a number of causal factors behind the success of these two loops, including the requirements of the law (the Reserve), the availability of benchmarks against which to monitor (the Reserve), the presence of a 'watchdog' (the KNP in this case), the responsiveness of the manager and users, and the ability to self-organise. Whilst an in-depth analysis of these is beyond the scope of this paper and is examined by Pollard and Du Toit (in press), a key point is that the 'watchdog' role, which is as important as any of the other roles, is often overlooked and hence needs to be recognised as critical. The SAM project is now refining, together with users, an adaptive monitoring management system. The essence of this system is that there are different levels of concern related to the status of a resource in question (e.g. river flow) and hence different management actions linked to each. The severity of the 'worry level' is given via an indicator or TPC, which is collaboratively determined (McLoughlin 2011). The important principle, therefore, is that there is an envelope of levels of concern - supported by a clear rationale - and each is linked to different management actions.

The SRI (Phase I) has demonstrated that the requirements of the Ecological Reserve are not being met with regard to quantity in all six rivers, despite an improved policy environment and the initiation of integrated water resources management(Pollard et al.2010). Thiscan, in part, beattributed to lags that are an inherent part of the process of reform in a complex environment; setting the Reserve today does not mean that it will be met tomorrow. However, it is important to consider what makes certain delays unacceptable. In many cases, especially in the northern WMAs, issues such as tardiness in authorisation, unlawful use, the lack of integration of water resources management and supply, weak monitoring and enforcement, and the dearth of skills and capacity all need to be addressed as a matter of urgency. In others, such as in the Crocodile and Komati rivers, recent advances in water resources management provide real possibilities for improvement. The KNP has again been an important roleplayer in this regard, acting both as a catalyst for change and as a constructive stakeholder.

\section{Participation in wider catchment forums: The development of the Catchment Management Strategy}

The commitment to manage water holistically is captured in the National Water Act, which requires that water resources are managed from a catchment perspective. Ultimately, CMAs will take over the management of the water resources, especially with regard to water allocation and protection of the resource. Representation is secured through various structures such as catchment management committees or forums (CMCs or CMFs) and water user associations (WUAs). In many cases, the KNP has initiated forums that could be considered CMF precursors or prototypes. In the case of the Crocodile River catchment, the KNP has spearheaded the establishment of the Crocodile River Forum (CRF) and for the Sabie River, the Sabie River Working Group, which started in 1991. Today, the KNP participates in fora that cover all major rivers entering the park and plays an important role in tabling its position and interests in water resource decisions.

The relationship of the KNP with and its influence on the agriculture or forestry sectors are also worth mentioning. An example is the Sabie River Working Group, which managed to save the Sabie River in the KNP from a flow stoppage during the 1992 drought (Biggs et al. 2010). The KNP initiated this forum and was an active member but it was chaired by an irrigation farmer from the Hazyview area for many years. Another example is the Marula Weir, which was to be constructed in the Crocodile River for irrigation purposes. The KNP managed to stop the building of the weir even though the foundation had been started (Venter et al. 1995). Although the relationship between the irrigation farmers and the KNP was strained as a result, the two parties have managed to build a good relationship subsequently as mutual understanding improved. More recently, the KNP supported the efforts of a local initiative, namely the 'Save the Sand' programme, in advocating the withdrawal of poorly managed afforestation in the upper Sand River catchment. The plantations, conceived as labour-creation

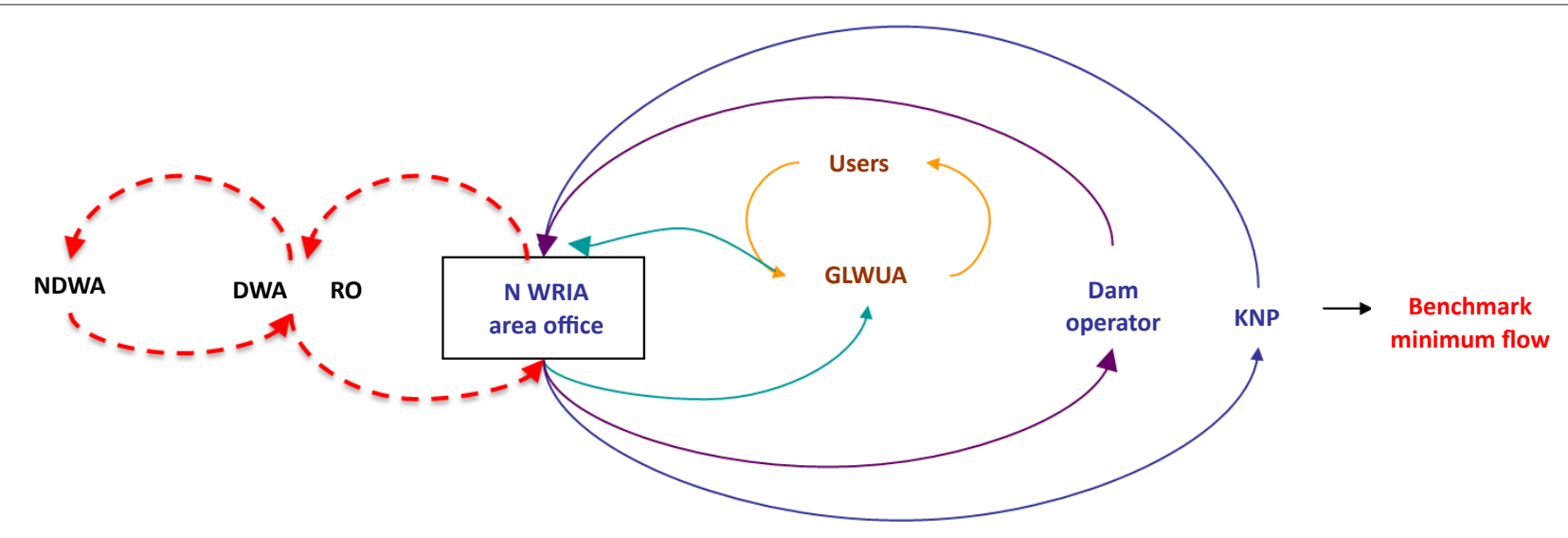

NDWA, National Department of Water Affairs; DWA RO, Department of Water Affairs Regional Office; GLWUA, Groot Letaba Water User Association; KNP, Kruger National Park; NWRIA, National Water Resources Infrastructure Agency.

FIGURE 4: Functional feedback loops in the Letaba catchment. Feedback loops are evident when information that arises (discovered or learnt) as part of a management process is passed on to an (appropriate) body who takes (appropriate and effective) action and feeds this back. The self-regulation component is provided for by the water user association regulating its own members through internal agreements and practice. Note the weak linkages to the regional and national Department of Water Affairs. 
schemes under the Bantustan regime, covered excessively steep slopes, wetlands and riparian zones, which caused sediment problems and reduced base flows (Figure 1). The support from the KNP was not so much about actual effects (which were most heavily felt before the rivers enter the KNP boundaries), but rather about the principle of wise use and management of natural resources. Many more such examples are available in both peer-reviewed (e.g. Kingsford et al. 2011; McLoughlin 2011) and grey literature (reports submitted to the WRC under project K5/1797).

\section{Lessons that emerged from learning in action}

This section deals with the emerging outcomes of the transformation described in this paper, which can now be reflected upon and used as guidance for a way forward. Many important learnings in this field are already available, for example, descriptions and discussion of the:

- transformation from a more closed to a more open style of management in the KNP (Venter et al. 1995)

- general steps involved in SAM and the related progress (Kingsford et al. 2011)

- spread of SAM from a rivers application to a wide range of domains, not only in the KNP but also across general conservation applications in South Africa (Freitag et al. in review)

- mechanics of actual operationalisation of feedbacks built around thresholds (McLoughlin 2011).

This paper has taken a more direct look at the philosophical and paradigmatic changes, and styles of management and research, that have characterised the transformation we describe. The overview considered the fuller range of initiatives relevant to water resource management in the park and its surrounds, both before and after the inception of explicit or formal adaptive management. The particular lessons elucidated by this review thus overlap with several lessons from each of the studies described, but also reinforce or complement those lessons with additional value.

The observation that the SAM approach has been widely accepted within the KNP and that no fundamental alternatives for river management have appeared to date, may mean that the KNP and other active collaborators are beginning to understand the complexity required to broker decisions effectively on a continuing (dynamic) basis. The fact that there have been ongoing structured research programmes on rivers seems to imply that, at least in the context of the KNP, active levels of research involvement may be a prerequisite for coping in a fast-changing world with difficult resource management issues.

The process of adopting SAM was, as described earlier, a process of recursive action over time. Although the SAM approach began mainly with biophysical aspects within the park, over time, the recognition of wider socio-ecological systems (initially catchments) became central, with more active systemic connections being realised. This meant that, initially, management procedures became more inclusive of issues as they emerged and ultimately more complicated. There came a point where managers were overwhelmed, which resulted in a retraction to requisite simplicities (Holling \& Gunderson 2002), so that the management process did not become untenable.

What is the overall meaning of findings of this particular overview for the KNP and for the wider community who are engaged in SAM of rivers? The main achievement for the KNP has been the development of a new way for approaching its conservation mandate based on complexity principles. This led to the emergence of a management framework over nearly 15 years (detailed in Pollard and Du Toit [2007] and described earlier). The SAM framework, although developed through a focus on rivers, can be embraced for the management of ecosystems as wholes. In summary, the framework requires that management be directed towards achieving a desired state (Biggs \& Rogers 2003; Breen at al. 2000). Indeed, this has fundamentally re-orientated the management of the KNP, staff and resource allocations. As explained earlier, once this higher-order statement had been debated and captured in a vision, it provided the basis for the development of objectives and endpoints that could be readily traced back to the vision. This process has allowed a much closer partnership to develop between researchers, managers and field staff, with a strong sense of buy-in and collective learning made possible (Pollard \& Du Toit 2005).

An important shift in the management principle governing semi-arid savannas is that the desired future state is not a stable state but one that is based on a fundamental recognition of variability as an overarching characteristic to confer resilience. Thus, judicious management is predicated on understanding the underlying ecosystem drivers and characteristics of the system in question. Moreover, since river systems are dynamic and in a continual state of flux, it is necessary to monitor conditions and to revisit management objectives. System dynamics need to be understood in the broader context of events both inside and outside of the protected area.

Adopting the SAM framework, with its key features being a clear vision informed by stakeholder involvement, an objectives hierarchy, a consideration of management options, an apparatus of TPCs and a reflective evaluation process consisting of feedback loops, has been challenging but important for KNP staff. Pollard and Du Toit (2007) noted that the collaborative role of researchers and management in developing TPCs and ensuring they are met has been cited as a powerful motivation for monitoring staff, such as rangers and wardens, who then become a key link in the iterative SAM cycle. The value of involving field staff in setting management objectives cannot be underestimated with regard to developing commitment and buy-in. The TPCs are hypotheses and hence the TPCs and the associated 'desired state', should be audited and refined in a reflexive manner (McLoughlin 2011; Pollard \& Du Toit 2006). 
Knowledge management is a challenge that needs to be addressed. Biggs and Rogers (2003) point out that after a TPC has been tabled, several unpredictable threads of information tend to emerge as implementation proceeds. These threads may or may not be documented at the appropriate level of quality (i.e. everything is taken to be equally relevant). These authors recommend a continual 'roping together' of the information so that the organisation benefits as a whole, thus averting disparate and isolated approaches. The SAM approach is likely to generate a wealth of field data that need to be recorded, captured and made accessible. (McLoughlin 2011; Pollard \& Du Toit 2006). This is seen as one of the challenges for the KNP. At present, the Park is developing a knowledge management system based on a geographic information system as well as non-spatial databases. The intention is to draw science and management together by putting data to productive use rather than archiving for historical purposes only. Once the challenging aspects of knowledge management have been negotiated they can lead to the need for shared learning. Here the KNP has experimented with the formation of 'Communities of Practice' (Lave \& Wenger 1991) from, initially, a core of enthusiasts whose task it is to continually rework and improve the SAM system and make it more accessible for use by others. Experience shows that there is a need for programmes run by the KNP to be integrated so that, by drawing on a wider variety of specialists and practitioner experiences, more realistic TPCs can be set in the future (Pollard \& Du Toit 2006). Nonetheless, lessons for integrating new concepts, such as ecosystems services and social ecology, with more traditional approaches are yet to be learned.

Pollard and Du Toit (2008) argue that the legislative environment for water resources management and the approach of integrated water resources management afford a particularly strong basis and coherent currency for the adaptive management of river systems. The approach in the KNP thus complements - and puts into practice - the spirit and intent of the National Water Act. In the case of river management, an additional challenge has been to broaden horizons and deal with the realities of conflicting drivers and objectives. River systems are common-property resources (Pollard \& Cousins 2008). In South Africa, there is no private ownership of water and flow through a portion of land does not confer inalienable rights on that land owner. Moreover, because demand is viewed from a catchment-scale perspective of the total water resources, there will inevitably be tradeoffs and compromises in working towards more equitable and sustainable configurations for catchments (Pollard \& Du Toit 2008). These two factors necessitate that stakeholders, including protected area staff, participate in water resources management where different interests and demands on the water resources are used to negotiate water sharing. Fortunately for the KNP, the new legislative environment has provided strong support for the concept of sustainability through the provision of the Reserve, which not only provides a benchmark for monitoring, but also carries legislative 'clout', strengthening the KNP's position as 'watchdog' (Pollard \& Du Toit 2008). This is critical given that infringements of the Ecological Reserve are evident in all rivers flowing through the park (Pollard et al. 2010).
Importantly, the KNP staff do not only monitor the rivers, but link outputs clearly to different actions according to the severity of the infringement (McLoughlin 2011), the transparency of which is important for monitoring staff (Pollard \& Du Toit 2006). Although the systems are still being strengthened and successful responsive action nonetheless varies, the basis for building feedback loops is in place. Indeed, as mentioned earlier, these feedbacks are essential for adaptive management, for without these, learning cannot happen (McLoughlin 2011; Pollard \& Du Toit 2006; Pollard \& Du Toit in press).

\section{Conclusion}

In conclusion, it is important to remember that adaptive management is not an end in itself, but a process that evolves as new learnings are brought to bear. As a result of the challenges confronted in addressing changes in rivers, the KNP has charted new ground in management, research and outreach. The approach embraces the challenge of managing a sensitive, complex system in a context where uncertainty is always an underlying factor. It encourages the 'first bold step forward' where 'implementation paralysis' can often hamper decision making. By using the best available information to set TPCs, SAM monitors trends and then demands reflection on collaboratively defined goals before jointly agreed action is initiated. The collaborative nature of implementing the SAM system forges a partnership between science and management - an approach that is seen as a way forward for parks, conservation and science (Folke, Carpenter et al. 2002; Van Wilgen \& Biggs 2010). Equally important is that such thinking has an institutional home for its eventual mainstreaming as management discourse, which the KNP may well provide.

\section{References}

Biggs, H. \& Rogers, K.H., 2003, 'An adaptive system to link science, monitoring and management in practice', in J.T. du Toit, K.H. Rogers \& H.C. Biggs, The Kruger Experience: Ecology and management of savanna heterogeneity, pp. 59-80, Island Press, Washington DC.

Biggs, H.C., Breen, C.M. \& Palmer, C.G., 2008, 'Engaging a window of opportunity: Synchronicity between a regional river conservation initiative and broader water law reform in South Africa', International Journal of Water Resources Development
$24(3), 329-343$.

Biggs, R., Westley, F.R. \& Carpenter, S.R., 2010, 'Navigating the back loop: fostering social innovation and transformation in ecosystem management', Ecology and Society $15(2), 9$, viewed on 15 January 2011, from http://www.ecologyandsociety. Society $15 / 2$, 9 , art9/

Braack, L., 1997a, A revision of parts of the management plan for the Kruger National Park. Vol. VII: An objectives hierarchy for the Kruger National Park, South African National Parks, Skukuza.

Braack, L., 1997b, A revision of parts of the management plan for the Kruger National Park. Vol. VIII: Policy proposals regarding issues relating to biodiversity
maintenance, maintenance of wilderness qualities, and provision of human maintenance, maintenance of wilderness qualition
benefits, South African National Parks, Skukuza.

Breen, C., Dent, M., Jaganyi, J., Madikizela, B., Maganbeharie, J., Ndlovu, J., et al., 2000,' 'The Kruger National Park Rivers Research Programme', Final report, Water Research Commission, Pretoria.

Breen, C., Quinn, N. \& Deacon, A., 1994, 'A description of the Kruger Park Rivers Research Programme', Second phase: Programme description: pp. 43.

Breen, C.M., Bestbier, R., et al., 1997, 'Integrating socio-economic and governance systems with ecological knowledge of structure and function of riparian system. The ecology and management of riparian corridors in Southern Africa', Proc. International Workshop, Kruger National Park, South Africa.

Carruthers, J., 1995, The Kruger National park: A social and political history, University of Natal Press, Pietermaritzburg.

Chunnett, F., 1990, 'Water Resources Planning of the Sabie River Catchment', Water Research Commision, 1(10).

Cumming, D.H.M. \& AHEAD Great Limpopo TFCA Working Group, 2004, 'Sustaining animal health and ecosystem services in large landscapes-2nd draft-Concept for a programme to address wildlife, livestock and related human and ecosystem health issues in the Greater Limpopo Trans-frontier Conservation Area', 24 pp., from http://www.wcs-ahead.org/workinggrps_limpopo.html 
Davies, B.R., O'Keeffe, J.H. \& Snaddon, C.D., 1995, 'River and Stream ecosystems in Southern Africa. Predictably unpredictable', in C.E. Cushing, K.W. Cummins \& G.W. Southern Africa. Predictably unpredictable', in C.E. Cushing, K.W. C
Minshall, River and Stream Ecosystems, Elsevier Press, New York.

Department of Water Affairs and Forestry, 2004a, Internal Strategic Perspective. Inkomati WMA, Pretoria.

Department of Water Affairs and Forestry, 2004b, Internal strategic perspective. Luvuvhu/Letaba WMA, Pretoria.

Department of Water Affairs and Forestry, 2004c, Internal Strategic Perspective, Olifants River WMA, Pretoria.

Department of Water Affairs and Forestry, 2004d, National Water Resources Strategy, Pretoria, Pretoria.

Department of Water Affairs and Forestry, 2009, Inkomati Water Availability Assessment: Water Requirements, Pretoria.

Dovie, D.B.K., Shackleton, C.M. \& Witkowski, E.T.F., 2006, 'Valuation of communal area livestock benefits, rural livelihoods and related policy issues', Land Use Policy 23, 260-271.

Du Toit, J.T., Rogers, K.H. \& Biggs, H.C., (eds.), 2003, The Kruger Experience. Ecology and Management of Savanna Heterogeneity, Island Press, Washington DC.

DWAF. See Department of Water Affairs and Forestry.

Folke, C., Carpenter, S., Elmqvist, T., Gunderson, L., Holling, C.S., Walker, B., et al., 2002, 'Resilience and sustainable development building adaptive capacity in a world of transformations', Ambio 31(5), 437-440.

Freitag, S., Biggs, H. \& Breen, C.M., in review, 'Fifteen years of the spread and maturation of adaptive management in South African National Parks: organisational learning in systems perspective', in W. Freimund, S. McCool \& C.M. Breen (eds.), Engaging Complexity in Protected Area Management: Challenging Occam's Razor, University of KwaZulu-Natal Press, Pietermaritzburg, South Africa.

Gaylard, A., Owen-Smith, N. \& Redfern, J., 2003, 'Surface water availability: Implications for heterogeneity and ecosystems processes', in J.T. du Toit, K.H. Rogers \& H.C. Biggs, The Kruger Experience. Ecology and Management of Savanna Heterogeneity, pp. 171-188, Island Press, Washington DC.

Holling, C.S. \& Gunderson, L.H., 2002, 'Resilience and adaptive cycles', in L.H. Gunderson \& C.S. Holling, Panarchy: Understanding transformations in human and natural systems, pp. 25-62, Island Press, Washington DC.

Jezewski, J. \& Roberts C.P.R., 1986, 'Estuarine and lake freshwater requirements', Technical Report TR129, Department of Water Affairs.

King, J.M., Tharme, R.E. \& De Villers, M.S., 2000, 'Environmental flow assessments for rivers: manual for the Building Block Methodology', Water Resources Commission Report TT 131/100, Pretoria, South Africa.

Kingsford, R.T., Biggs, H.C. \& Pollard, S.R., 2011, 'Strategic adaptive management in freshwater protected ares and their rivers', Biological Conservation 144(4), 11941203.

Lave, J. \& Wenger, E., 1991, Situated Learning. Legitimate peripheral participation, University of Cambridge Press, Cambridge.

Mabunda, D., Pienaar, D.J., et al., 2003, 'The Kruger National Park: A century of management and research', in J.T. du Toit, K.H. Rogers \& H.C. Biggs, The Kruger management and research', in J.T. du Toit, K.H. Rogers \& H.C. Biggs, The Kruger
Experience. Ecology and Management of Savanna Heterogeneity, pp. 3-21, Island Experience. Ecology and
Press, Washington DC.

McLoughlin, C.A., Deacon, D., Sithole, H. \& Gyedu-Ababio, T., 2011, 'History, rationale, and lessons learned: Thresholds of potential concern in Kruger National Park river adaptive management', Koedoe 53(2), Art. \#996, 27 pages. doi:10.4102/koedoe. v53i2.996.

Niehaus, I., 2001, Witchcraft, power and politics. Exploring the occult in the South African Lowveld, Pluto Press, London.

Noss, R.F., 1990, 'Indicators of monitoring biodiversity: a hierarchical approach', Conservation Biology 4, 355-364.

O'Keeffe, J. \& Coetzee, Y., 1996, 'Status report of the Kruger National Park Rivers Research Programme: A synthesis of results and assessment of progress to January 1996', Pretoria, Water Research Commission: pp. 63.

O'Keeffe, J.H. \& Davies, B.R., 1991, 'Conservation and management of the rivers of the Kruger National Park: suggested methods for calculating instream flow needs', Aquat. Conserv. Mar. Freshw. Ecos. 1, 1-17.

Owen-Smith, N. \& Ogutu, J., 2003, 'Rainfall influences on ungulate population dynamics', in J.T. du Toit, K.H. Rogers \& H.C. Biggs, The Kruger Experience. Ecology and Management of Savanna Heterogeneity, pp. 422-446, Island Press, Washington DC.

Pearce, F., 1992, Dammed, Bodley Head, London.

Peel, M., 1999, 'Cattle grazing in the northern forestry area (DWAF): Stocking densities guidelines', Report produced for the Save the Sand Programme: pp. 31.

Pienaar, U.d.V., 1970, 'Water resources of the Kruger Park', African Wildlife 24, 180-191.

Pollard, S. \& Du Toit, D., 2006, 'Recognizing heterogeneity and variability as key characteristics of savannah systems: The use of Strategic Adaptive Management as an approach to river management within the Kruger National Park, South Africa', Report for UNEP/GEF Project No. GF/2713-03-4679, Ecosystems, Protected Areas and People Project.

Pollard, S.R. \& Du Toit, D., 2007, 'Guidelines for Strategic Adaptive Management: Experiences from managing the rivers of the Kruger National Park, South Africa', IUCN/ UNEP/GEF Project No. GF/ 2713-03-4679, Ecosystems, Protected Areas and IUCN/ UNEP/GEF Project No. GF/ 2713-03-4679, Ecosystems, Protected Areas
People Project, Planning and managing protected areas for global change.
Pollard, S., Du Toit, D.R., Reddy, Y. \& Thlou, T., 2007, Guidelines for the development of catchment management strategies: towards equity, efficiency and sustainability, catchment management strategies: towards equity,

Pollard, S. \& Du Toit, D., 2008, 'The Letaba Catchment: Contextual profile on factors that constrain or enable compliance with environmental flows', Shared River Programme, DRAFT Report, Project K5/1711.

Pollard, S. \& Du Toit, D., 2009, 'Drawing Environmental Water Allocations into the World of Realpolitik: Emerging Experiences on Achieving Compliance with
Policy in the Lowveld Rivers, South Africa. Implementing Environmental Flow Policy in the Lowveld Rivers, South Africa.
Allocations', Port Elizabeth, South Africa.

Pollard, S. \& Du Toit, D., in press, The importance of feedback loops in ensuring catchment resilience: An examination of six catchments in South Africa, n.p.

Pollard, S., Riddell, E., et al., 2010, Compliance with the Reserve: How do the Lowveld Rivers measure up?, Report prepared for the Water Research Commission: Reserve assessment of lowveld rivers (Del. 1), n.p.

Pollard, S., Shackleton, C., et al., 2003, 'Beyond the Fence: People and the Lowveld Ecology and Management of Savanna Heterogeneity, pp. 422-446, Island Press, Washington DC

Pollard, S.R., Biggs, H. \& Du Toit, D., 2008, 'Towards a Socio-Ecological Systems View of the Sand River Catchment, South Africa: An exploratory Resilience Analysis', Report to the Water Research Commission, Project K8/591, Pretoria.

Pollard, S.R. \& Cousins, T., 2008, 'Towards integrating community-based governance of water resources with the statutory frameworks for Integrated Water Resources Management: A review of community-based governance of freshwater resources communal wetlands', Water Research Commission Report TT.328/08, Pretoria, Water Research Commission.

Pollard, S.R., Mendiguren, J.C.P.D., et al., 1998, 'Save the Sand phase I. Feasibility study: The development of a proposal for a catchment plan for the Sand river catchment', Pretoria, Department of Water Affairs and Forestry, Department of Agriculture and Land Affairs: 378.

Pollard, S.R. \& Du Toit, D., 2008, 'Integrated Water Resources Management in complex systems: How the catchment management strategies seek to achieve
sustainability and equity in water resources in South Africa', Water SA Special sustainability and equity in water resources in Sou
Edition IWRM 34(6), from http://www.wrc.org.za

Pollard, S.R., Weeks, D.C., et al., 1994, 'Effects of the 1992 drought on the aquatic biota of the Sabie and Sand rivers', in A pre-impoundment study of the Sabie-Sand River System, Eastern Transvaal, with special reference to predicted impacts on the Kruger national Park, vol. 2, Pretoria, Water Research Commission Report: pp. 122.

Ramutsindela, M.F., 2002, 'The perfect way to end a painful past? Makuleke land deal in South Africa', Geororum 33, 15-24.

Refugee, Research, et al., 2002, 'A park for the people? Great Limpopo Transfrontier Park - Community Consultation in Coutada 16, Mozambique', Preliminary research report (March), Acornhoek, South Africa.

Roberts, C.P.R., 1983, 'Environmental constraints of water resources developments', Proc S. Afr. Inst. Civil Engineers, n.p.

Rogers, K.H., 2005, 'The real river management challenge: Integrating scientists, stakeholders and service agencies', River Res. Applic 22(2), 269-280.

Rogers, K.M. \& Bestbier, R., 1997, Development of a protocol for the definition of the desired state of riverine systems in South Africa, Department of Environmental Affairs and Tourism, Pretoria.

RSA, 1998, National Water Act, Act 36 of 1998, Republic of South Africa Government Gazette, Cape Town, Republic of South Africa.

Russell, I.A. \& Rogers, K.H., 1988, 'The distribution and composition of fish communities in major rivers of the Kruger National Park', in S. Kienzle and $\mathrm{H}$. Maaren, Proceedings of the fourth South African national hydrological symposium, 20-22 November 1989, University of Pretoria, University Pretoria: 281-288.

Smith, R.E. \& Scott, D.F., 1992, 'The effects of afforestation on low flows in various regions of South Africa', Water SA 18(3), 185-194.

Stadler, J., 1994, 'Generational relationships in a lowveld village: questions of age, household and tradition', MSc thesis, University of Witwatersrand.

Van Aarde, R., Whyte, I. \& Pimm, S., 1999, 'Culling and the dynamics of the Kruger National Park African elephant population', Animal Conservation 2(4), 287-294.

Van Wilgen, B.W. \& Biggs, H., 2010, 'A critical assessment of adaptive ecosystem management in a large savanna protected area in South Africa', Biological Conservation, n.p.

Venter, F.J. \& Deacon, A.R., 1995, 'Managing rivers for conservation and ecotourism in the Kruger National Park', Water Science and Technology 32, 227-233.

Venter, F.J., Gerber, F., Deacon, A.R., Viljoen, P.C. \& Zambatis, N., 1995, 'Ekologiese Impakverslag: ' $n$ ondersoek na die voorgestelde Maroelastuwal in die Krokodilrivier' [Ecological Impact Report: An investigation of the proposed Maroela weir in the Crocodile river], Report $\mathrm{Nr}$ 1/95 Scientific services, Skukuza.

Venter, F.J., Naiman, R.J., Biggs, H.C. \& Pienaar, D.J., 2008, 'The Evolution of Conservation Management Philosophy: Science, Environmental Change and Social Adjustments in Kruger National Park', Ecosystems 11, 173-192.

Weeks, D.C., Pollard, S.R., et al., 1992, 'Downstream effects on the aquatic biota of the Sand River following the collapse of Zoeknog dam', Report submitted to Water Research Commission.

Water Research Commission, 2001, 'State of the rivers report. Crocodile, SabieSand and Olifants river systems', Pretoria, Water Research Commission: pp. 40. 


\section{Appendix 1}

TABLE 1: Timeline of the Kruger National Park Rivers Research Programme outlining goals and focus (from Breen, C., Dent, M., Jaganyi, J., Madikizela, B., Maganbeharie, J., Ndlovu, J., et al., 2000, 'The Kruger National Park Rivers Research Programme', Final report, Water Research Commission, Pretoria; O'Keeffe, J. \& Coetzee, Y., 1996, 'Status report of the Kruger National Park Rivers Research Programme: A synthesis of results and assessment of progress to January 1996', Pretoria, Water Research Commission: pp. 63).

\begin{tabular}{ll}
\hline Date & Detail \\
\hline 1986 & $\begin{array}{l}\text { DWA indicated intentions to allocate water to sustain the natural environment. Increasing demands for water were compromising the integrity of South } \\
\text { African rivers. }\end{array}$ \\
1987 & KNPRRP envisioned at a workshop convened by DWAF. \\
1988 & KNPRRP initiated jointly by DWAF, FRD (now NRF), WRC, National Parks Board (now SANParks).
\end{tabular}

\section{Phase I: Scientific research}

In 1992 evaluation commended KNPRRP for quality of scientific research, but indicated the need for a more structured programme and proposed appointment of a Programme Managing Director, which was accepted; questions as to whether activities lacked integration to achieve desired outcomes; lack of explicit goals noted.

\section{4-1996 Phase II: Research-based implementation}

Task: Management needed to be strengthened.

Focus on enhanced predictive capabilities and contextualising these within management in support of decision making.

Programme started with a programme description (Breen, C., Quinn, N. \& Deacon, A., 1994, 'A description of the Kruger Park Rivers Research Programme', Second phase: Programme description: pp. 43).

Focus:

- Geographical focus on the Sabie River; conceptual focus on decision support and development of predictive capabilities.

- Research focus complemented these.

- Capacity building through participation in Programme.

Goals:

- To achieve a common understanding of water quality and quantity requirements to sustain the natural environments of rivers that flow through the KNP.

- To develop, refine and implement methods for predicting and monitoring the responses of the natural environments of rivers flowing through the KNP to fluctuating flow and variable water quality.

Research in support of decision making:

- Definition of a desired state.

- Need to identify representative reaches for monitoring.

- Need to improve and link predictive capabilities.

- Need for integrated modelling of catchment runoff and channel transformation.

- Need to develop a meta-database.

- Development of an integrated modelling system that incorporated water quality capabilities.

- Monitoring and auditing recognised as a fundamental link in the iterative process of adaptive management.

Strengths:

Comprehensive review by O'Keeffe, J. \& Coetzee, Y., 1996, 'Status report of the Kruger National Park Rivers Research Programme: A synthesis of results and assessment of progress to January 1996', Pretoria, Water Research Commission: pp. 63:

- Existing information on rivers synthesised and easily accessed.

- Development of a decision support system.

- Establishment of protocols for defining desired state and representative reaches.

- Enhanced predictive capacities for biotic modelling.

- Development of linkages between biotic and abiotic predictive models.

- Development of an integrated catchment information system and adopted by user agencies (no longer applicable).

- Detailed inventories and status of certain components of Sabie River available.

- Programme has advanced approach to rivers research in South Africa and pioneered development of an explicit hydrology-hydraulic-geomorphology-biotic response framework.

- Significant contributions to assessment of IFRs of rivers.

Weaknesses:

- Failure to engage DWAF and DEATa effectively; government expectations insufficiently met.

- Weaknesses with internal and external communication.

- Intention to initiate research in water quality linked to predictive modelling not effective; good quality of Sabie River noted.

- Failure to engage effectively with other interested researchers.

- Few new projects initiated owing to focus on existing knowledge; strengths became vulnerable in certain areas.

- Unclear decision making hierarchy to prioritise research programmes; led to discontent.

1997-2000 Phase III: Completion of first-generation practices and technologies

Overview:

- Complete first-generation procedures and technologies for SAM of rivers.

- Engage managers and stakeholders to promote information and technology transfer.

- Promote corrective action to allow the previously disadvantaged to participate.

- A key difference was (1) the focus on broadening the base of understanding to River Forums and other stakeholders and (2) application of knowledge, understanding and tools to the management of river systems (Breen, C.M., Bestbier, R., et al., 1997, 'Integrating socio-economic and governance systems with ecological knowledge of structure and function of riparian system. The ecology and management of riparian corridors in Southern Africa', Proc. International Workshop, Kruger National Park, South Africa).

Goals:

- As for Phase II.

- Third goal added: to achieve corrective action through enhancing individual and institutional capacity in the conceptualisation, implementation and management of transdisciplinary research on river systems.

Subsidiary goals:

- Strategies and action plans for the integrated management of at least three rivers providing flow in the KNP (Sabie, Olifants, Crocodile or Letaba).

- Improved understanding and application of ecological, economic and social principles in management of natural environment of rivers flowing through the KNP.

- Strategies and action plans implemented for meeting national and emerging policy (e.g. CBD, Helsinki Rules, Agenda 21) on at least three river systems (Sabie, Olifants, Crocodile or Letaba). 
TABLE 1 (Continues...): Timeline of the Kruger National Park Rivers Research Programme outlining goals and focus (from Breen, C., Dent, M., Jaganyi, J., Madikizela, B., Maganbeharie, J., Ndlovu, J., et al., 2000, 'The Kruger National Park Rivers Research Programme', Final report, Water Research Commission, Pretoria; O'Keeffe, J. \& Coetzee, Y., 1996, 'Status report of the Kruger National Park Rivers Research Programme: A synthesis of results and assessment of progress to January 1996', Pretoria, Water Research Commission: pp. 63).

Date Detail

- An effective communication strategy.

- Partnership programmes developed and operationalised with two historically 'Black' universities.

- Previously marginalised researchers working in partnership with experienced sub-programme managers.

- An effective education programme.

- River monitoring programmes for at least three rivers, which enabled stakeholders to evaluate whether goals and objectives were being achieved.

- Exchange of principles and techniques derived in the programme with other regions and river basins in southern Africa.

- Formation of the Southern African Rivers Network to share information and exchange expertise.

- Conference on Integrated River Management. 